\title{
Identification of Novel Antiviral Compounds Targeting Entry of Hantaviruses
}

\author{
Jennifer Mayor ${ }^{1,2}$, Giulia Torriani ${ }^{1,2}$, Olivier Engler ${ }^{2}$ and Sylvia Rothenberger ${ }^{1,2, *}$ \\ 1 Institute of Microbiology, University Hospital Center and University of Lausanne, Rue du Bugnon 48, \\ CH-1011 Lausanne, Switzerland; jennifer.mayor@unil.ch (J.M.); giulia.torriani@supsi.ch (G.T.) \\ 2 Spiez Laboratory, Swiss Federal Institute for NBC-Protection, CH-3700 Spiez, Switzerland; \\ Olivier.Engler@babs.admin.ch \\ * Correspondence: Sylvia.Rothenberger-Aubert@chuv.ch; Tel.: +41-21-314-51-03
}

Citation: Mayor, J.; Torriani, G.; Engler, O.; Rothenberger, S.

Identification of Novel Antiviral Compounds Targeting Entry of Hantaviruses. Viruses 2021, 13, 685. https://doi.org/10.3390/v13040685

Academic Editors:

Kumiko Yoshimatsu and Hiroaki Kariwa

Received: 19 March 2021

Accepted: 15 April 2021

Published: 16 April 2021

Publisher's Note: MDPI stays neutral with regard to jurisdictional claims in published maps and institutional affiliations.

Copyright: (C) 2021 by the authors Licensee MDPI, Basel, Switzerland. This article is an open access article distributed under the terms and conditions of the Creative Commons Attribution (CC BY) license (https:// creativecommons.org/licenses/by/ $4.0 /)$.

\begin{abstract}
Hemorrhagic fever viruses, among them orthohantaviruses, arenaviruses and filoviruses, are responsible for some of the most severe human diseases and represent a serious challenge for public health. The current limited therapeutic options and available vaccines make the development of novel efficacious antiviral agents an urgent need. Inhibiting viral attachment and entry is a promising strategy for the development of new treatments and to prevent all subsequent steps in virus infection. Here, we developed a fluorescence-based screening assay for the identification of new antivirals against hemorrhagic fever virus entry. We screened a phytochemical library containing 320 natural compounds using a validated VSV pseudotype platform bearing the glycoprotein of the virus of interest and encoding enhanced green fluorescent protein (EGFP). EGFP expression allows the quantitative detection of infection and the identification of compounds affecting viral entry. We identified several hits against four pseudoviruses for the orthohantaviruses Hantaan (HTNV) and Andes (ANDV), the filovirus Ebola (EBOV) and the arenavirus Lassa (LASV). Two selected inhibitors, emetine dihydrochloride and tetrandrine, were validated with infectious pathogenic HTNV in a BSL-3 laboratory. This study provides potential therapeutics against emerging virus infection, and highlights the importance of drug repurposing.
\end{abstract}

Keywords: orthohantaviruses; arenavirus; ebolavirus; viral hemorrhagic fever; antiviral screening; entry inhibitors; GFP

\section{Introduction}

Orthohantaviruses (hereafter referred to as hantaviruses), in the family Hantaviridae, are human pathogenic viruses causing severe diseases with high mortality rate and represent therefore a serious challenge for public health. The prototypic Hantaan (HTNV) and Seoul (SEOV) viruses are widespread in Asia, where they cause hemorrhagic fever with renal syndrome (HFRS), with up to $15 \%$ case-fatality. In the Americas, the Sin Nombre (SNV) and Andes (ANDV) viruses are associated with hantavirus cardiopulmonary syndrome (HCPS), with up to $40 \%$ mortality [1,2]. Orthohantaviruses are distributed worldwide, which corresponds to the geographical distribution of their reservoir hosts, namely rodents, shrews, moles and bats.

Human infections are accidental and occur through inhalation of contaminated rodent excreta. Transmission via aerosols requires the capacity to break the species barrier and productively infect cells of the human respiratory epithelium. Upon first replication at the site of entry, orthohantaviruses disseminate systemically through the bloodstream. The therapeutic options are currently limited to supportive care and the only available vaccine, Hantavax ${ }^{\circledR}$, is approved in several Asian countries, but not in Europe or the U.S.A. [3,4]. Given the worldwide distribution of orthohantaviruses, novel medical approaches for treatment and prevention are of high priority. 
Orthohantaviruses, arenaviruses and filoviruses can cause viral hemorrhagic fevers (VHFs) and their life cycle shows some common features, especially at the level of viral attachment and entry [5-7]. Viral attachment and entry represent the first and most fundamental steps in virus zoonotic transmission and infection. It therefore represents a promising target for therapeutic intervention in order to block viruses before they can take control of the host cell and produce viral progeny. In this study, using a fluorescencebased screening assay, we identified new antivirals against HTNV and ANDV, as well as Lassa virus (LASV) and Ebola virus (EBOV). The screening assay was performed using a validated pseudotype platform based on recombinant vesicular stomatitis reporter virus (VSV) bearing the glycoprotein of interest and encoding enhanced green fluorescent protein (EGFP) [8-10]. EGFP expression allows the quantitative detection of infection and the identification of compounds affecting viral entry.

As $80 \%$ of the world population depends on traditional medicine [11], including the use of herbal medicinal products, we screened a phytochemical library containing 320 natural compounds and identified novel small molecular compounds with antiviral activity against HTNV and ANDV, as well as LASV and EBOV. Together, our data demonstrate that our screening platform can detect compounds with varying degrees of antiviral activity and therefore facilitates drug discovery to fight emerging virus infections.

\section{Materials and Methods}

\subsection{Cells}

Human lung carcinoma alveolar epithelial (A549) cells were maintained in Dulbecco's modified Eagle medium (DMEM)- $10 \%$ [v/v] fetal calf serum (FCS) at $37^{\circ} \mathrm{C}$ under $5 \%$ $\mathrm{CO}_{2}$ atmosphere. Monkey kidney epithelial (Vero E6) cells were maintained in Biochrom minimum essential media (MEM) with Earle's salts supplemented with $10 \%[v / v]$ FCS, $0.625 \%$ L-glutamine, $0.5 \%$ penicillin-streptomycin and 0.5\% NEAA (Biochrom, Cambridge, United Kingdom) at $37^{\circ} \mathrm{C}$. For infection studies, cells were seeded in $24-, 48$ - or 96 -well plates and cultured $16 \mathrm{~h}$ until cell monolayer formation.

\subsection{Plasmids and Reagents}

pWRG/HTNV-M [12] was kindly provided by Connie. S. Schmaljohn (U.S. Army Medical Research Institute of Infectious Diseases, Fort Detrick, MD, USA). The expression plasmid pI18 for the GPC of ANDV strain CHI-7913 was kindly provided by Nicole Tischler (Molecular Virology Laboratory, Fundación Ciencia \& Vida, Santiago, Chile) and has been described previously [13]. Expression plasmids encoding Lassa virus GPC strain Josiah and VSV-G were reported previously [8]. The expression vector encoding Ebola virus strain Makona was kindly provided by Mark Page (The National Institute for Biological Standards and Control, South Mimms, UK).

The phytochemical library was from Prestwick Chemicals (stock concentration $10 \mathrm{mM}$ in DMSO, Illkrich Graffenstaden, France). The selected positive hits monensin sodium salt, rotenone, tetrandrine, as well as 5-( $N$-ethyl- $N$-isopropyl) amiloride (EIPA) were from SigmaAldrich (Buchs, Switzerland), nitrarine dihydrochloride was provided by Latoxan (Portes lès Valence, France), and emetine dihydrochloride was from EMD Millipore (Darmstadt, Germany). The CellTiter-Glo ${ }^{\circledR}$ Assay System was obtained from Promega (Madison, WI, USA).

\subsection{Pseudotype Virus Production and Viruses}

The pseudotype viral system is based on the recombinant VSV* $\Delta \mathrm{G}$-Luc vector in which the glycoprotein gene $(G)$ had been deleted and replaced with genes encoding green fluorescent protein (EGFP; indicated by an asterisk) and luciferase (Luc) [14]. Pseudoviruses were generated as reported previously [8,9]. Recombinant human adenovirus serotype 5 (AdV5) expressing EGFP has been described previously [15]. HTNV strain 76/118 [16] was propagated in Vero E6 cells (Vero C1008, ATCC CLR 1586) in the BSL-3 containment laboratory at Spiez Laboratory. 


\subsection{Microscopy}

ImageXpress ${ }^{\circledR}$ Micro XLS Widefield High-Content Screening System (Molecular Devices, San Jose, CA, USA) was used to visualize and quantify the number of EGFP-infected cells. Per each well, one image, covering $5.32 \%$ of the well surface, was captured using two fluorescent channels, i.e., DAPI and GFP. Images were then analyzed with MetaXpress software. To detect and analyze EGFP-infected cells, two settings were fixed: the typical cell area and the GFP expression. Cell area was first determined by the presence of nuclei based on DAPI stained images, and with several manual delimitations of cell edges based on bright field images. Upon first identification, the number of cells expressing EGFP was determined.

\subsection{Dynamic Range Determination}

The titration of VSV* $\Delta \mathrm{G}-\mathrm{Luc}(\mathrm{VSV}-\mathrm{G})$ was performed by two-fold serial dilution on monolayers of Vero E6 cells. After $1 \mathrm{~h}$ of infection, fresh medium was added, and cells were incubated overnight at $37^{\circ} \mathrm{C}$. Infection was quantified by measuring EGFP-positive infected cells per well site using ImageXpress ${ }^{\circledR}$ Micro XLS Widefield High-Content Screening System (Molecular Devices). Data were analyzed with MetaXpress and GraphPad Prism 7 softwares.

\subsection{ROC Curve}

Confluent monolayers of A549 cells were either treated with $50 \mu \mathrm{M}$ EIPA for $30 \mathrm{~min}$ ( 25 wells) or untreated ( 25 wells), followed by infection with VSV* $\Delta$ G-Luc(HTNV-G) in the presence of the inhibitor. After $16 \mathrm{~h}$ of incubation, cells were washed with medium, fixed with $2 \%$ PFA, and the nuclei were stained with NucBlue ${ }^{\mathrm{TM}}$ Fixed Cell ReadyProbes ${ }^{\mathrm{TM}}$ Reagent (DAPI) following manufacturer's instruction (ThermoFisher, Waltham, MA, United States). Data were acquired and analyzed with MetaXpress and GraphPad Prism 7 softwares.

\subsection{Antiviral Screening}

Confluent monolayers of A549 cells were pre-treated with candidate compounds dissolved in DMEM $10 \%$ FCS (final concentration $10 \mu \mathrm{M}$ ) for $45 \mathrm{~min}$. Around $2.5 \times 10^{5}$ infectious unit (IU) /mL (MOI of 0.3) of VSV* $\Delta$ G-Luc(HTNV-G), VSV* $\Delta$ G-Luc(ANDV-G), VSV* $\Delta$ GLuc(EBOV-G), or VSV* $\Delta$ G-Luc(LASV-G) were added in the presence of candidate compounds. After $2 \mathrm{~h}$ of infection with indicated pseudoviruses, the inoculum was removed, and the cells were washed and incubated for $16 \mathrm{~h}$ in complete medium containing $20 \mathrm{mM}$ ammonium chloride. Infection was first quantified by measuring EGFP-positive infected cells by fluorescent microscopy, and analyzed with MetaXpress software. Compounds demonstrating $\geq 20 \%$ reduction in cellular ATP levels according to CellTiter-Glo ${ }^{\circledR}$ assay (Promega) were removed from the screen.

\subsection{Drug Inhibition Assay}

Confluent monolayers of A549 or Vero E6 cells were pre-treated with drugs for $30 \mathrm{~min}$ at $37^{\circ} \mathrm{C}$ under $5 \% \mathrm{CO}_{2}$, followed by infection with the indicated viruses in presence of the drugs for $1.5 \mathrm{~h}$ at $37^{\circ} \mathrm{C}$. After incubation, cells were washed twice with DMEM $10 \%$ FCS supplemented with $20 \mathrm{mM}$ of ammonium chloride and incubated for $16 \mathrm{~h}$ at $37^{\circ} \mathrm{C}$ with the presence of ammonium chloride. Finally, infection was quantified by counting EGFPpositive infected cells per well using an EVOS FLoid Cell Imaging Station (ThermoFisher).

For time-of-addition experiments, infection with the indicated viruses was performed in A549 cells. Then, $1.5 \mathrm{~h}$ post-infection, the cells were subsequently washed twice with DMEM $10 \%$ FCS supplemented with $20 \mathrm{mM}$ of ammonium chloride and incubated for $16 \mathrm{~h}$ at $37^{\circ} \mathrm{C}$ with the presence of ammonium chloride and appropriate concentration of each antiviral. Productive infection was quantified by counting EGFP-positive infected cells per well using an EVOS FLoid Cell Imaging Station (ThermoFisher). 


\subsection{Pathogenic Virus Validation}

Vero E6 cells were pre-treated with increasing concentrations of EIPA, monensin sodium salt, emetine dihydrochloride and tetrandrine for $30-45 \mathrm{~min}$ at $37^{\circ} \mathrm{C}$, followed by HTNV (strain 76/118) infection for $1 \mathrm{~h}$ at $37^{\circ} \mathrm{C}$ in presence of the drug. Cells were subsequently washed once with MEM $2 \%$ FCS and incubated with MEM 2\% FCS containing appropriate drug concentrations for 2 days.

To calculate the therapeutic index (TI), confluent monolayers of Vero E6 cells were treated with EIPA, tetrandrine, and emetine dihydrochloride starting at $100 \mu \mathrm{M}$ concentration, followed by a $\sim 1.5$-fold dilution for two days. After $48 \mathrm{~h}$, cells were treated with $1 \%$ triton-100 (diluted in water) for $15 \mathrm{~min}$ at $37^{\circ} \mathrm{C}$ in order to totally lyse the cells and obtain the background values. Cell viability was then measured using CellTiter-Glo ${ }^{\circledR}$ Assay System (Promega). The median toxic dose $\left(\mathrm{TD}_{50}\right)$ was calculated based on the cell viability values, while the median effective dose $\left(\mathrm{ED}_{50}\right)$ on cell infectivity with HTNV. Therapeutic index was finally calculated as follows: $\mathrm{TD}_{50} / \mathrm{ED}_{50}$.

\subsection{RT-qPCR Analysis}

Viral RNA was isolated using RNeasy ${ }^{\circledR}$ Plus Universal Mini Kit (QIAGEN, Hilden, Germany) following the manufacturer's instructions. Quantification of viral RNA was performed using a real-time quantitative polymerase chain reaction (RT-qPCR) assay specific for the HTNV nucleocapsid coding region in a LigthCycler ${ }^{\circledR} 96$ (Roche, Mannheim, Germany) following the manufacturer's instructions. Cells treated in parallel with the drugs were analyzed for viability using the CellTiter-Glo ${ }^{\circledR}$ Assay System (Promega).

\subsection{Statistical Analysis}

Graphical representation and statistical analysis were performed using GraphPad Prism 7 software. Data are means + SD $(n=3)$, and $p$ values of $<0.05$ were considered statistically significant.

\section{Results}

\subsection{Determination of the Dynamic Range for Luminescence Detection}

To overcome the biosecurity limitation for work with highly pathogenic viruses, we used a validated pseudotype platform. Briefly, we used a recombinant vesicular stomatitis virus (VSV), in which the glycoprotein gene was deleted and replaced with reporter genes encoding enhanced green fluorescent protein (EGFP, indicated by an asterisk) and firefly luciferase (Luc). Then, glycoproteins of interest from HTNV, ANDV, EBOV or LASV were provided in trans in the recombinant VSV $[5,8,9]$. The VSV-pseudotypes systems are replication-competent, but propagation-deficient, making them suitable for work under BSL-2 conditions.

Recombinant viruses expressing a fluorescent reporter are valuable for the rapid identification of candidate antiviral compounds [17,18]. To determine whether GFP encoded in our pseudoviruses could be used as a surrogate readout to rapidly test the activity of antiviral drug candidates, we first measured the number of EGFP-positive infected cells. Confluent monolayers of A549 cells were infected with two-fold serial dilution of $\mathrm{VSV}^{*} \Delta \mathrm{G}-\mathrm{Luc}(\mathrm{VSV}-\mathrm{G})$ for $16 \mathrm{~h}$. The cells were then fixed with $2 \%$ PFA for $20 \mathrm{~min}$ at RT and the nuclei were stained. The fluorescent microscope ImageXpress ${ }^{\circledR}$ Micro XLS Widefield High-Content Screening System (Molecular Devices) was used to measure and analyze the number of infected cells according to the average size of infected cells expressing EGFP (Figure 1A,B). As expected, the EGFP signal could be detected, when the viral concentration is between $5 \times 10^{7}$ and $2 \times 10^{5}$ infectious units (IU) $/ \mathrm{mL}$, allowing the quantification of infected cells. Our results demonstrate that GFP expression represents a valuable tool to monitor the number of infected cells, and thus pseudovirus entry in our screening platform. 


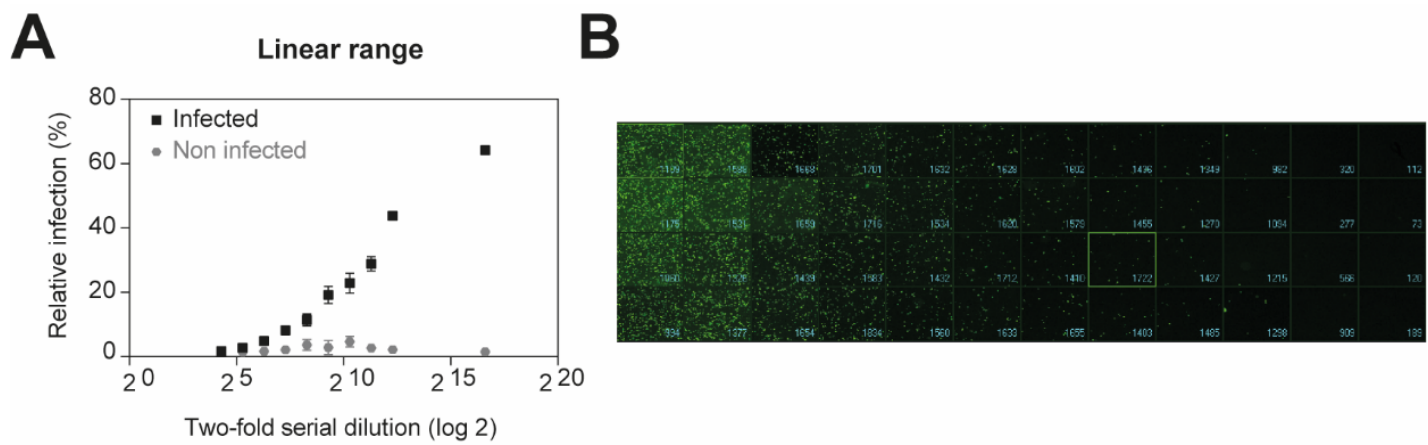

Figure 1. Determination of linear range for luminescent detection. Confluent monolayers of A549 cells were infected with two-fold serial dilution of VSV ${ }^{*} \Delta \mathrm{G}$-Luc(VSV-G) in DMEM $10 \% \mathrm{FCS}$ for $16 \mathrm{~h}$ at $37^{\circ} \mathrm{C}$ under $5 \% \mathrm{CO}_{2}$. EGFP-positive infected cells were measured by high-content imaging. (A) Quantified representation of EGFP-expression. (B) Representative images of reporter virus-infected A549 cells. Images for two-fold serial dilutions are presented.

\subsection{Establishment of a ROC Curve}

To further determine whether GFP expression and the size-based method could be used to statistically evaluate the antiviral activity of selected compounds, we performed receiver-operating characteristics (ROC) analysis. An ROC curve is a test of probability to determine how well a screening assay distinguishes treated infected cells and non-treated infected cells. More specifically, it shows the trade-off between sensitivity and specificity. Sensitivity is the proportion of treated cells identified correctly when a treatment is present. Similarly, specificity is the proportion of non-treated cells when no treatment is added. In other words, it is the probability to exclude negative results. An ideal ROC curve is a vertical line on the $y$-axis (specificity $=1.0$ ) with a horizontal line at sensitivity $=1.0$, while for an assay that is not better than random prediction, it is a diagonal line. The area under the curve (AUC) gives information about the model performances. An ideal AUC is 1.0, whereas a value of 0.5 corresponds to a random assay.

As many emerging human pathogenic viruses are transmitted via aerosols, we used A549 human lung epithelial cells as the model $[1,2,19]$, which are also known to be susceptible to HTNV infection [20]. To test the screening platform and confirm the potential to find novel antiviral compounds, we used VSV* $\Delta$ G-Luc(HTNV-G) and 5-(N-ethyl- $N$-isopropyl)amiloride (EIPA) previously shown to inhibit HTNV-G pseudovirus entry [9]. A549 cells were either non-treated or treated with $50 \mu \mathrm{M}$ EIPA for $30 \mathrm{~min}$, followed by infection with VSV $\Delta$ G-Luc(HTNV-G) in the presence of the inhibitor. After $16 \mathrm{~h}$ of incubation, cells were washed, fixed with $2 \%$ PFA, and stained. The number of infected cells was then analyzed through GFP expression and the size-based method using a fluorescent microscope (Figure 2A).

We obtained an AUC of 1 to discriminate between infected and non-infected cells (Figure 2B), and an AUC of 0.9483 between treated and non-treated infected cells (Figure 2C). This means that infected cells treated with EIPA have a $94.8 \%$ chance of being discriminated from non-treated infected cells. These results demonstrate the feasibility of using GFP expression to assess the antiviral activity of selected compounds.

A549 human lung epithelial cells are a suitable cell model to study aerosol-transmitted viruses. However, HTNV, ANDV, and EBOV are generally propagated on Vero E6 cells and the HTNV strain 76-118 is adapted to this cell line [16,21]. Using HTNV-G pseudotypes, we thus examined whether Vero E6 constitute a cell model to test the impact of EIPA. Confluent monolayers of Vero E6 or A549 cells were pre-treated with increasing concentrations of EIPA for $45 \mathrm{~min}$, and subsequently infected with VSV* $\Delta$ G-Luc(HTNV-G). After $90 \mathrm{~min}$, cells were washed and complete medium with $20 \mathrm{mM}$ ammonium chloride was added to cells in order to block further entry via low $\mathrm{pH}$-triggered membrane fusion. VSV ${ }^{*} \mathrm{G}$ Luc(HTNV-G) is similarly inhibited in both Vero E6 and A549 cells, demonstrating an inhibition of $\sim 78 \%$ and $70 \%$ at $30 \mu \mathrm{M}$, respectively (Figure $2 \mathrm{D}$ ). 
A
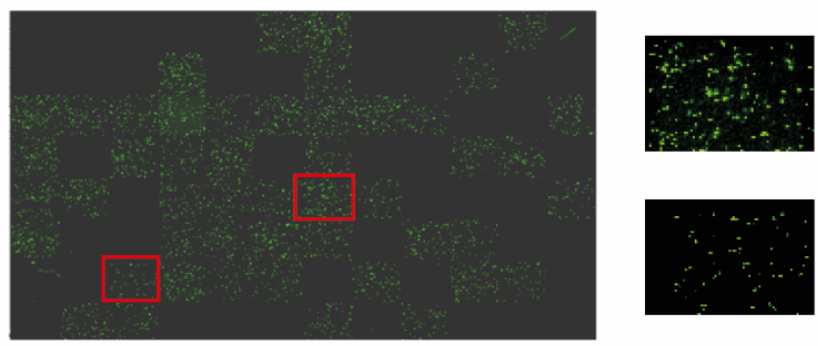

D

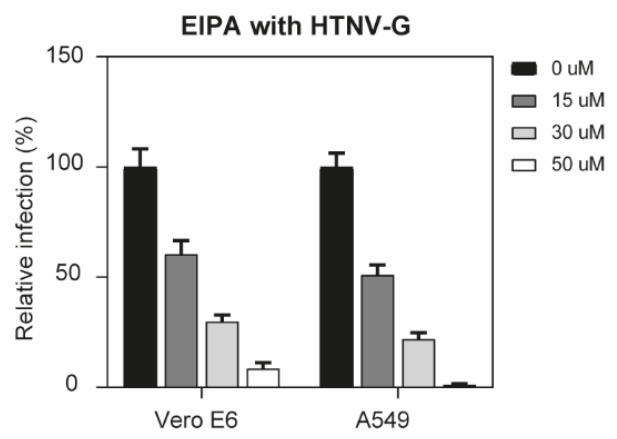

B

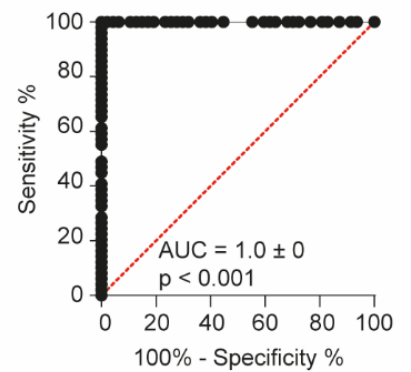

E

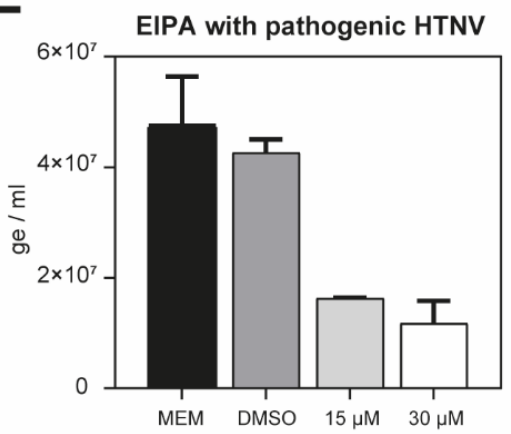

Figure 2. Performance of EGFP expression measurement as a method to differentiate non-treated from treated infected cells. (A) Representative image of a 96-well plate with two enlarged wells standing for treatment conditions. Three conditions were applied to confluent monolayers of A549 cells: no pre-treatment and no infection; no pre-treatment followed by infection with VSV* $\Delta \mathrm{G}$-Luc(HTNV-G) (upper right panel); or pre-treatment with $50 \mu \mathrm{M}$ EIPA for 30 min (lower right panel), followed by infection with VSV* $\Delta \mathrm{G}-\mathrm{Luc}(\mathrm{HTNV}-\mathrm{G})$ in the presence of the inhibitor. After $16 \mathrm{~h}$ of incubation, cells were washed, fixed with $2 \%$ PFA, and the nuclei were stained (DAPI). The number of infected cells was then analyzed through GFP expression using fluorescent microscope. Representation of EGFP expression on the XLS microscope. (B,C) ROC curves obtained for non-infected vs. infected cells (B) and for non-treated vs. EIPA-treated cells (C). The AUC and significance level are shown in each case. (D) EIPA inhibits HTNV-G in Vero E6 and A549 cells. Monolayers of Vero E6 or A549 cells were pre-treated with indicated concentration of EIPA for $45 \mathrm{~min}$ at $37^{\circ} \mathrm{C}$, followed by VSV* $\Delta \mathrm{G}$-Luc(HTNV-G) infection at $200 \mathrm{IU} /$ well for $90 \mathrm{~min}$. Cells were then washed and complete medium with $20 \mathrm{mM}$ ammonium chloride was added and incubated for $16 \mathrm{~h}$. The infection levels were assessed by counting the EGFP-positive infected cells. Data are means $+\mathrm{SD}$ $(n=3)$. (E) EIPA inhibits HTNV infection. Vero E6 cells were pre-incubated with EIPA at the indicated concentrations for $45 \mathrm{~min}$ at $37^{\circ} \mathrm{C}$, followed by HTNV infection for $1 \mathrm{~h}$ at $37^{\circ} \mathrm{C}$. Cells were subsequently washed once with medium and incubated with medium containing appropriate drug concentration for $48 \mathrm{~h}$. Infection levels were assessed by RT-qPCR. Data are means $+\mathrm{SD}(n=3)$ of genome per $\mathrm{mL}$.

Moreover, the inhibitory activity of EIPA was also evaluated on pathogenic HTNV infection. Confluent monolayers of Vero E6 cells were incubated with various concentration of EIPA for $45 \mathrm{~min}$, followed by HTNV infection at $37^{\circ} \mathrm{C}$ for $1 \mathrm{~h}$. Cells were washed once and incubated with medium containing appropriate EIPA concentration for $48 \mathrm{~h}$. We observed a decrease of $\sim 65 \%$ in viral production at an EIPA concentration of $30 \mu \mathrm{M}$ (Figure $2 \mathrm{E}$ ). This suggests that entry inhibitors could be potent antiviral drugs, and provides a first validation of our screening platform.

\subsection{High-Throughput Screening Assay for Identifying Entry Inhibitors}

Plants can be a very valuable source of new antiviral molecules. To identify novel antiviral therapeutics against hantaviruses, we screened 320 natural compounds of the Prestwick Phytochemical library. Monolayers of A549 cells were pre-treated with $10 \mu \mathrm{M}$ of compounds for $45 \mathrm{~min}$ and infected with VSV* $\Delta$ G-Luc(HTNV-G), VSV* $\Delta$ G-Luc(ANDV-G), $\mathrm{VSV}^{*} \Delta \mathrm{G}-\mathrm{Luc}(\mathrm{EBOV}-\mathrm{G})$, or VSV*${ }^{*} \mathrm{G}-\mathrm{Luc}(\mathrm{LASV}-\mathrm{G})$ in the presence of drugs. After $2 \mathrm{~h}$, the drugs were washed out to minimize the duration of drug exposure and unwanted 
off-target effects. The cells were then incubated in medium supplemented with ammonium chloride to block further entry via low $\mathrm{pH}$-triggered membrane fusion. The following day, cells were fixed with $2 \%$ PFA for $20 \mathrm{~min}$, and the nuclei were stained (DAPI). Productive infection was detected by EGFP expression measurement with ImageXpress ${ }^{\circledR}$ Micro XLS Widefield High-Content Screening System. To avoid artefacts due to toxicity, the candidate compounds underwent previous evaluation in a cell viability test that detects changes in cellular ATP levels under the exact assay conditions. Candidate inhibitors that resulted in $>20 \%$ reduced cell viability were excluded from the screen. We found that $88 \%$ of tested compounds are not toxic (Figure 3A).

A

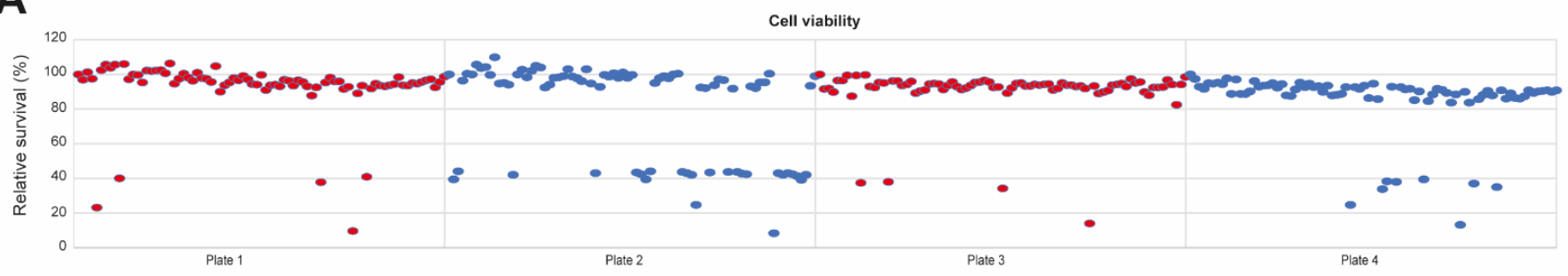

B

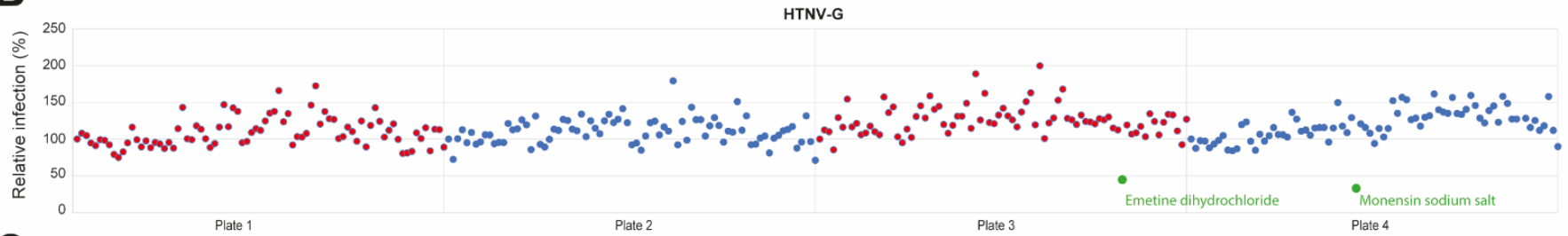

C

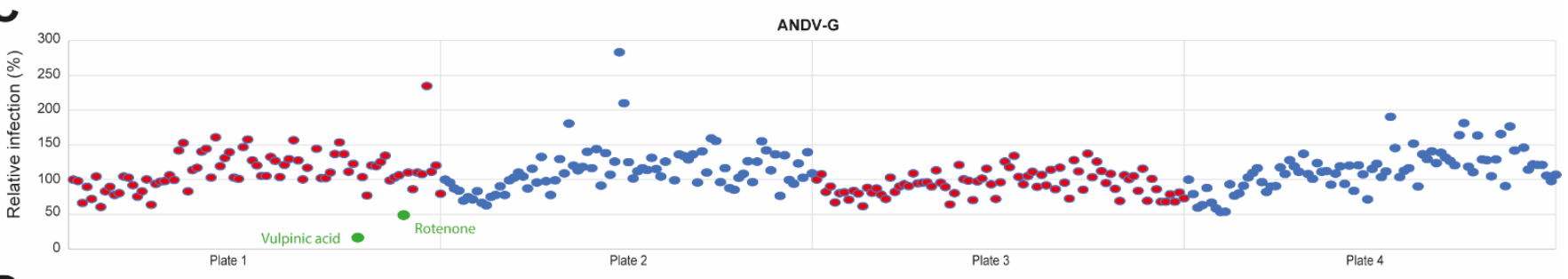

D

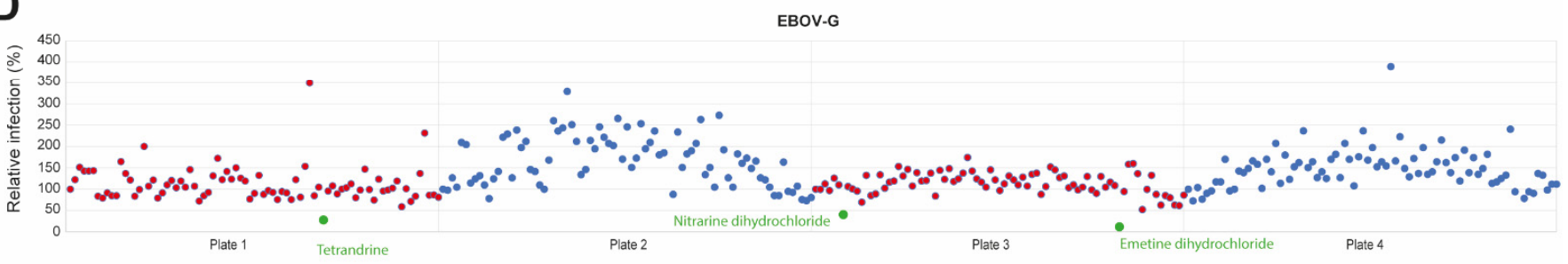

E

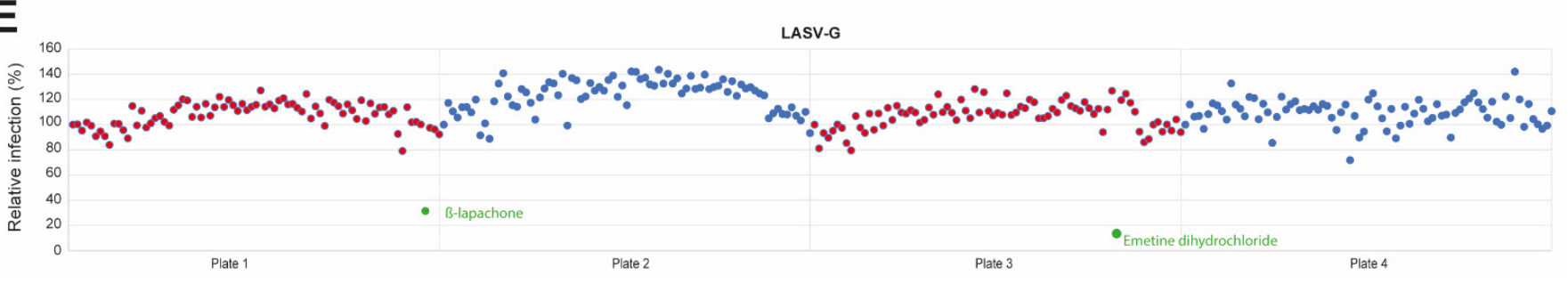

Figure 3. Screening of Prestwick Phytochemical library identified compounds reducing pseudoviruses entry. A549 cells were pre-treated with $10 \mu \mathrm{M}$ of compounds for $45 \mathrm{~min}$ and infected with VSV* $\Delta \mathrm{G}-\mathrm{Luc}(\mathrm{HTNV}-\mathrm{G}), \mathrm{VSV} * \Delta \mathrm{G}-\mathrm{Luc}(\mathrm{ANDV}-\mathrm{G})$, $\mathrm{VSV}^{*} \Delta \mathrm{G}$-Luc(EBOV-G) or VSV* ${ }^{*} \mathrm{G}$-Luc(LASV-G) in presence of the drugs. After $2 \mathrm{~h}$, cells were washed 3 times with medium containing $20 \mathrm{mM}$ ammonium chloride, followed by $16 \mathrm{~h}$ of incubation in the presence of the lysosomotropic agent. Infection was detected by EGFP and the control (DMSO) set at $100 \%$. (A) Cell viability was measured by the CellTiter-Glo ${ }^{\circledR}$ assay. The compounds demonstrating a reduction of $>20 \%$ in cellular ATP levels were considered toxic. (B-E) Infection was detected by EGFP expression and the control (DMSO) set at 100\%. The compounds reducing viral entry by $>50 \%$ are highlighted in green and names wrote underneath. 
The screening was performed with HTNV-G and ANDV-G, as well as with EBOV-G and LASV-G in order to compare the effects of inhibitors on different viral families and discern between drugs with broad-spectrum effects or virus-specific effects. Drugs with broad-spectrum effects can be of value because novel emerging viruses have huge impact on affected populations. In our analysis, compounds inhibiting the infection $>50 \%$ of at least one pseudovirus were considered as hits. We identified five compounds $(\sim 1.5 \%$ of the library) that reduced viral entry by $>50 \%$, namely tetrandrine, nitrarine dihydrochloride, rotenone, monensin sodium salt and emetine dihydrochloride (Figure 3B-E, highlighted in green). Tetrandrine and nitrarine dihydrochloride inhibited infection of EBOV-G, rotenone reduced ANDV-G infection and monensin sodium salt demonstrated an antiviral effect on HTNV-G. Emetine dihydrochloride showed a broad-spectrum inhibitory effect on HTNVG, EBOV-G and LASV-G. Moreover, the hits identified did not demonstrate cytotoxicity. Overall, these results suggest that the screening platform we developed can detect the antiviral activity of small molecule compounds.

\subsection{Characterization of Hits Identified in Primary Screen}

To further characterize the hits and determine the antiviral activity of each drug, we mapped dose-response curves while titrating the compounds. Confluent monolayers of A549 cells were treated with increasing concentration of tetrandrine, nitrarine dihydrochloride, rotenone, monensin sodium salt or emetine dihydrochloride for 45 min at $37^{\circ} \mathrm{C}$, followed by incubation with the pseudoviruses in the presence of the drugs. The inoculum was then removed and the cells were further incubated in medium containing ammonium chloride to block secondary infection with low $\mathrm{pH}$-triggered membrane fusion. Tetrandrine, nitrarine dihydrochloride and rotenone tended to have virus-specific antiviral activity (Figure $4 \mathrm{~A}-\mathrm{C}$ ). The three compounds did not show any cytotoxicity under the assay conditions. We found that tetrandrine drastically decreased entry of VSV* $\Delta$ G-Luc(ANDVG), VSV* ${ }^{*}$ G-Luc(EBOV-G), and VSV* $\Delta$ G-Luc(LASV-G) and had a slightly lower antiviral activity against $\mathrm{VSV}^{*} \Delta \mathrm{G}-\mathrm{Luc}(\mathrm{HTNV}-\mathrm{G})$. Nitrarine dihydrochloride demonstrated a similar reduction in infection for $V_{S V}^{*} \Delta \mathrm{G}$-Luc(EBOV-G), while VSV* $\Delta$ G-Luc(ANDV-G) entry was reduced at $85 \%$ at $7 \mu \mathrm{M}$ concentration. Rotenone had antiviral activity mainly against $\mathrm{VSV}^{*} \Delta \mathrm{G}-\mathrm{Luc}(\mathrm{ANDV}-\mathrm{G})$ and $\mathrm{VSV}^{*} \Delta \mathrm{G}-\mathrm{Luc}(\mathrm{LASV}-\mathrm{G})$. All pseudoviruses tested were inhibited by both monensin sodium salt (Figure 4D) and emetine dihydrochloride, which demonstrated a reduction in infection in a dose-dependent manner (Figure 4E).

To delineate the impact of the compounds on viral entry and post-entry steps of infection, we performed a "time-of-addition" experiment. To do this, the inhibitors were added at specific concentrations at $1.5 \mathrm{~h}$ post-infection (Figure $5 \mathrm{~A}$ ). As a control, we used a recombinant adenovirus 5 (AdV5), a non-enveloped virus, that does not pass through the endosome to get into the cells. Tetrandrine, rotenone and monensin sodium salt reduced viral entry of HTNV-G, while the drug did not show antiviral activity against AdV5 (Figure 5B). Moreover, they did not demonstrate any antiviral activity at a post-entry step. These data showed that these compounds can affect the entry of tested VHFs, most likely by inhibiting their exit from the endosomal compartment.

In contrast, emetine dihydrochloride demonstrated a potent antiviral activity against AdV5 at entry level, indicating that the compound had an impact on later steps of the viral cycle. Since AdV5 at the post-entry level was also completely inhibited by emetine dihydrochloride, this suggests that the compound had no effect on the endosomes, but most probably on other steps of the viral infection, such as replication of the VSV and AdV5. 
A

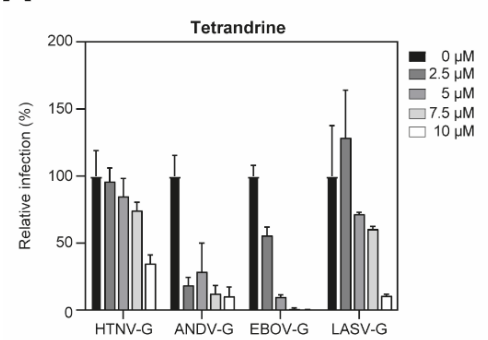

D

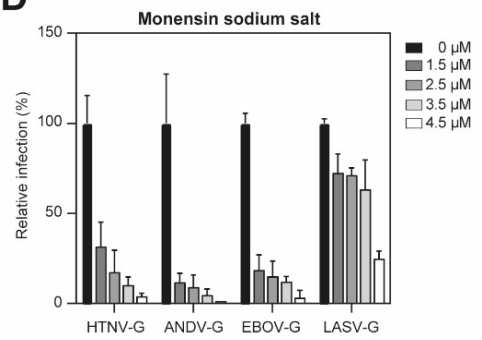

B

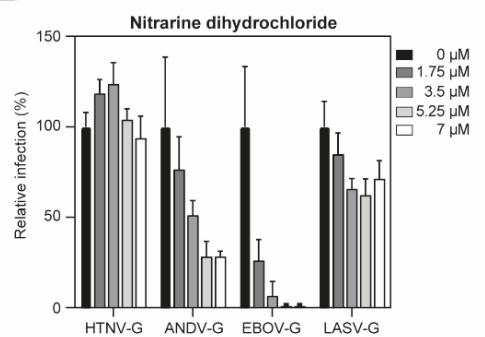

$\mathrm{E}$

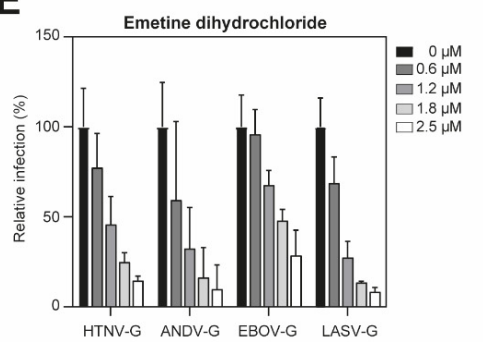

C

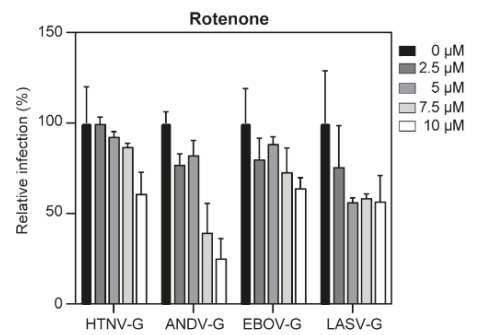

Figure 4. Tetrandrine (A), nitrarine dihydrochloride (B), rotenone (C), monensin sodium salt (D) and emetine dihydrochloride differentially (E) affect infection of VSV* $\Delta \mathrm{G}$-Luc(HTNV), VSV* $\Delta \mathrm{G}-\mathrm{Luc}(\mathrm{ANDV}), \mathrm{VSV} * \Delta \mathrm{G}-\mathrm{Luc}(\mathrm{EBOV})$ and $\mathrm{VSV}^{*} \Delta \mathrm{G}$-Luc(LASV) pseudotypes in A549 cells. A549 cells were pre-treated with different compounds at increasing concentrations for $45 \mathrm{~min}$ at $37^{\circ} \mathrm{C}$, followed by infection with the pseudoviruses in the presence of the drug for $90 \mathrm{~min}$ at $200 \mathrm{IU} /$ well. Complete medium with $20 \mathrm{mM}$ ammonium chloride was added and incubated for $16 \mathrm{~h}$. The infection levels were assessed by counting the EGFP-positive infected cells. Cell toxicity was assessed in parallel on uninfected cells by measuring ATP content. Data are means $+\mathrm{SD}(n=3)$.

B

A

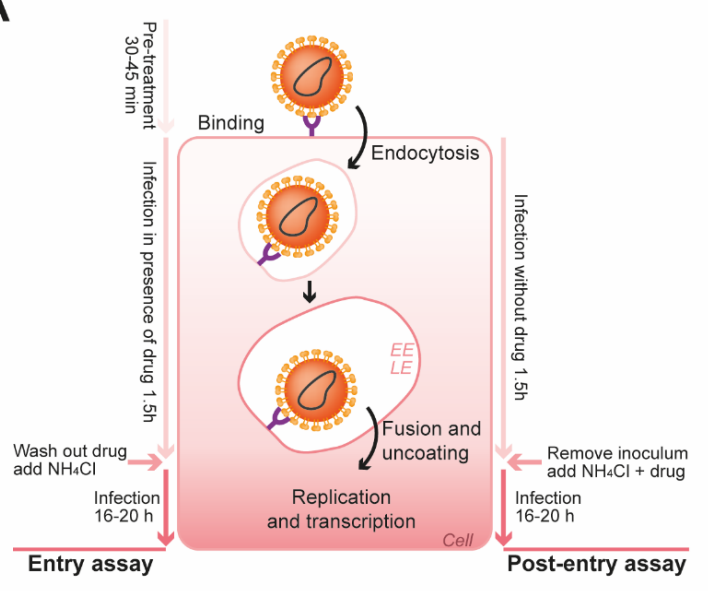
Entry assay Post-entry assay

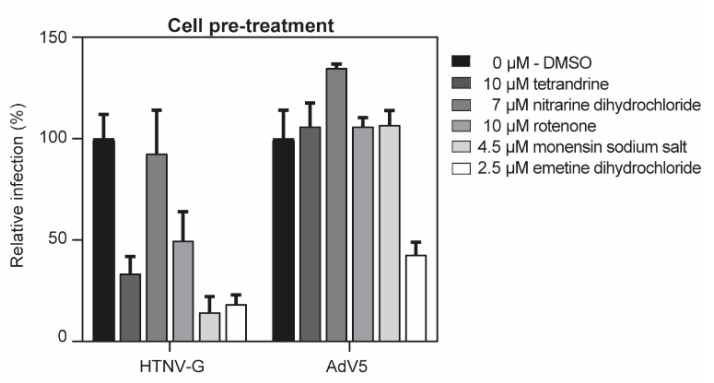

C

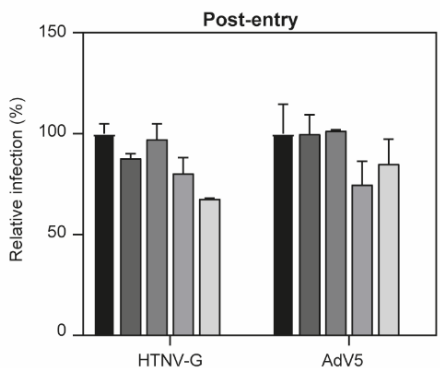

- $0 \mu \mathrm{M}$ - DMSO $10 \mu \mathrm{M}$ tetrandrine 10 $\mathrm{M}$ ritranine $4.5 \mu \mathrm{M}$ monensin sodium salt

Figure 5. Emetine dihydrochloride is broad-spectrum inhibitor in A549 cells. (A) Schema of the entry (left) and post-entry assay (right). EE, early endosome; LE, late endosome. (B) A549 cells were pre-treated with indicated compounds at specific concentrations for $45 \mathrm{~min}$ at $37^{\circ} \mathrm{C}$, followed by infection with the pseudoviruses in the presence of the drug at $200 \mathrm{IU} /$ well. After $90 \mathrm{~min}$, complete medium with $20 \mathrm{mM}$ ammonium chloride was added and further incubated for $16 \mathrm{~h}$. The infection levels were assessed by counting the EGFP-positive infected cells. Cell toxicity was assessed in parallel on uninfected cells by measuring ATP content. Data are means + SD $(n=3)$. (C) Time-of-addition experiment. A549 cells were infected with $\mathrm{VSV}^{*} \Delta \mathrm{G}-\mathrm{Luc}(\mathrm{HTNV}-\mathrm{G})$, or AdV5-GFP at $200 \mathrm{IU} /$ well and treated with indicated drug concentration after $1.5 \mathrm{~h}$ of infection. Infection levels were assessed by counting EGFP-positive infected cells. Data are means $+\mathrm{SD}(n=3)$. 


\subsection{Validation of Selected Antiviral Drugs with Pathogenic HTNV}

In a first step of validation, we tested the compounds demonstrating high antiviral activity on VSV $\Delta$ G-Luc(HTNV-G) in Vero E6 cells, as previously done with EIPA.

As observed in A549 cells, entry of VSV* $\Delta$ G-Luc(HTNV-G) into Vero E6 cells was also reduced in the presence of tetrandrine, monensin sodium salt and emetine dihydrochloride (Figure 6). No cytotoxicity was observed under the conditions of our assay. The overall similarity of the inhibitor profile in two different cell lines further supports a role for antiviral activity of tetrandrine, monensin sodium salt and emetine dihydrochloride on HTNV-G infection.

A

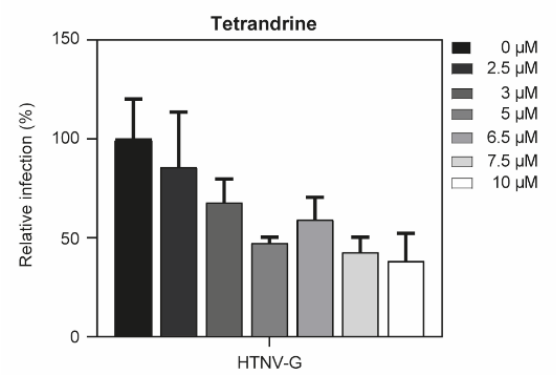

B

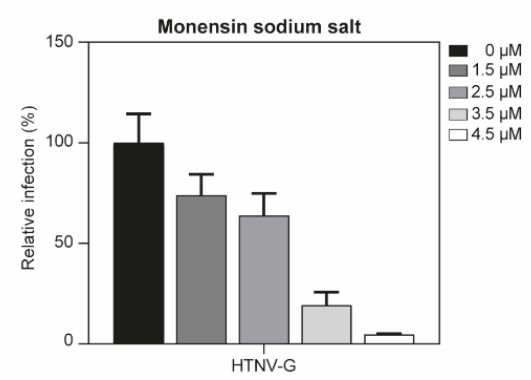

C

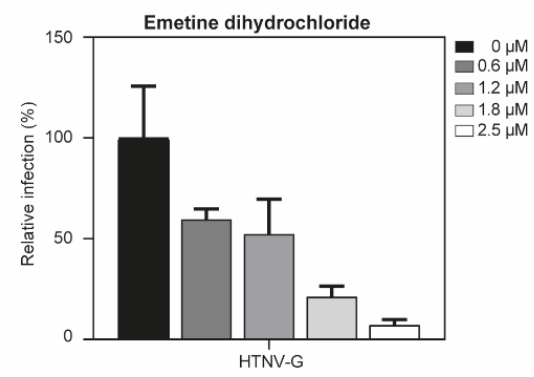

Figure 6. Treatment with tetrandrine, monensin sodium salt and emetine dihydrochloride in Vero E6 cells. (A-C) Monolayers of Vero E6 cells were pre-treated with the indicated drugs at given concentrations and then infected with VSV* $\Delta$ GLuc(HTNV-G). After $90 \mathrm{~min}$, cells were washed and complete medium with $20 \mathrm{mM}$ ammonium chloride was added and further incubated for $16 \mathrm{~h}$. The infection levels were assessed by counting the EGFP-positive infected cells. Data are means $+\mathrm{SD}(n=3)$.

Next, we determined whether our compounds also inhibit infectious HTNV in BSL-3 laboratory, based on their efficacy to reduce HTNV-G pseudovirus infection in previous screens and characterizations. We selected three compounds, monensin sodium salt, emetine dihydrochloride, and tetrandrine, for follow up analysis.

Following 45 min drug pre-treatment, pathogenic HTNV was added on Vero E6 cells in the presence of the antiviral compound for $1 \mathrm{~h}$. Cells were washed once and incubated with medium for 2 days. Cells were lysed and the level of virus infection was detected by RT-qPCR. Tetrandrine and emetine dihydrochloride drastically reduced HTNV infection (Figure 7A,B). Unfortunately, the treatment with monensin sodium salt showed cytotoxicity under the conditions of our assay. We then calculated the toxicity index (TI) to determine the relative safety of the drugs EIPA, emetine dihydrochloride and tetrandrine (Figure 7D). To this end, Vero E6 cells were treated under the infection assay conditions from 1 to $100 \mu \mathrm{M}$. Then, $48 \mathrm{~h}$ post-treatment, cells were lysed with $1 \%$ Triton-100 to obtain the background values. EIPA has a low toxicity effect compared to emetine dihydrochloride and tetrandrine (Figure $7 \mathrm{C}, \mathrm{D}$, toxic dose $\left(\mathrm{TD}_{50}\right)$ ). The relative safety of the compounds according to their respective inhibitory effect on HTNV infection indicated that emetine dihydrochloride is the compound showing the highest relative safety with a therapeutic index of $>7 \times 10^{7}: 1$, while EIPA and tetrandrine have a lower therapeutic index of 729:1 and 6.92:1, respectively. Taken together, our data show that the screening platform is able to identify entry inhibitors. 
A

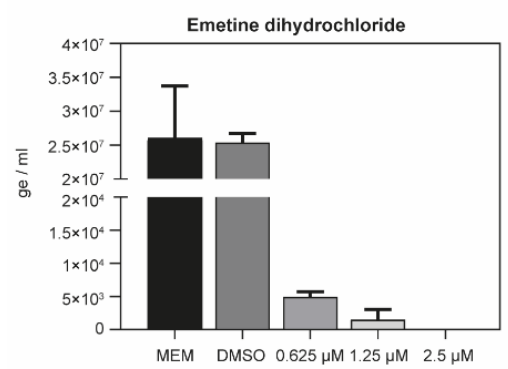

B

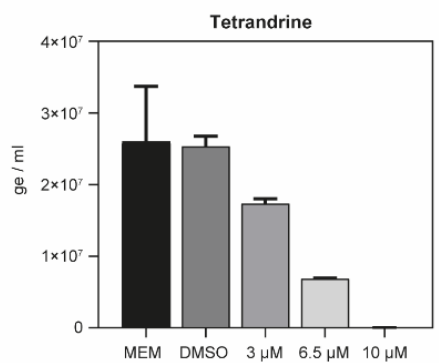

C

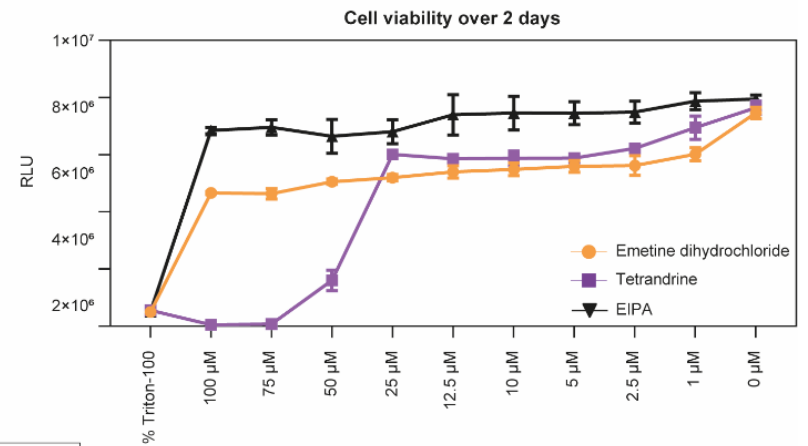

D

\begin{tabular}{|l|c|c|c|}
\hline & Toxic dose $\left(\mathrm{TD}_{50}\right)$ & Effective dose $\left(\mathrm{ED}_{50}\right)$ & Therapeutic index $(\mathrm{TI})$ \\
\hline EIPA & $8873 \mu \mathrm{M}$ & $11.19 \mu \mathrm{M}$ & 729.94 \\
\hline Emetine dihydrochloride & $752.5 \mu \mathrm{M}$ & $9.9^{*} 10^{-6} \mu \mathrm{M}$ & $7.5^{*} 10^{7}$ \\
\hline Tetrandrine & $27.54 \mu \mathrm{M}$ & $3.98 \mu \mathrm{M}$ & 6.92 \\
\hline
\end{tabular}

Figure 7. Validation with authentic pathogenic viruses. (A,B) Vero E6 cells were pre-incubated with emetine dihydrochloride (panel A), or tetrandrine (panel B) at the indicated concentrations for $45 \mathrm{~min}$ at $37^{\circ} \mathrm{C}$, followed by HTNV infection for $1 \mathrm{~h}$ at $37^{\circ} \mathrm{C}$. Cells were subsequently washed once with medium and incubated with medium containing appropriate drug concentrations for $48 \mathrm{~h}$. Infection levels were assessed by RT-qPCR. Data are means + SD $(n=3)$ of genome per ml. (C) Cell viability over two days. Monolayers of Vero E6 cells were treated with the indicated concentration of emetine dihydrochloride or tetrandrine under the assay conditions (A,B). After $48 \mathrm{~h}$, intracellular ATP levels were measured using CellTiter-Glo ${ }^{\circledR}$ assay. Data are means $\pm \mathrm{SD}(n=3)$ of relative light units (RLU). (D) Calculation of the therapeutic index (TI). The therapeutic index is defined as toxic dose $\left(\mathrm{TD}_{50}\right)$ /effective dose $\left(\mathrm{ED}_{50}\right)$.

\section{Discussion}

The lack of licensed antivirals to prevent VHF infection underlines the importance to develop methods for the identification of new therapeutics against these viruses. One promising line of research is the repurposing of drugs, which is time saving and therefore constitutes a major advantage in an outbreak context. Moreover, investigating the antiviral potential of natural compounds also represents a great advantage, as over $80 \%$ of the world's population depends on traditional medicine, including the use of herbal medicinal products, as a first source of healthcare [11]. Moreover, many modern drugs are developed on active compounds isolated from plants. The use of medicinal plants to fight viral infections deserves further investigation.

To discover novel antiviral agents against viral entry into host cells, we used a powerful platform based on a recombinant VSV-pseudoviruses carrying an EGFP reporter gene $[5,8,9]$. This pseudovirus platform was used in multiple studies to uncover entry factors for hantaviruses, arenaviruses and filoviruses, among others. The studies showed a very close correlation of VSV-pseudoviruses with the authentic viruses [7,22-28]. In a first step, we demonstrated the potential of the system to evaluate antiviral compounds at a lower level of biological containment. This pseudotype platform can be applied for a broad range of enveloped viruses and thus provides great possibilities to identify drugs capable of blocking viral entry. The GFP reporter gene encoded in our pseudoviruses could be used as an alternative readout and demonstrated a very stable fluorescence.

Entry into host cells represents a crucial step of viral infection, which determines cell tropism and disease potential. To validate our screening platform, we used a potent inhibitor of macropinocytosis, EIPA, which showed antiviral activity against both HTNV-G and ANDV-G in our previous studies $[5,8,9]$. First, our analysis using the ImageXpress ${ }^{\circledR}$ Micro XLS Widefield High-Content Screening System (Molecular Devices) to visualize and quantify the number of EGFP-infected cells showed a decrease in HTNV-G infection, when we treated the cells with $50 \mu \mathrm{M}$ EIPA. We then further validated the antiviral activity of EIPA using pathogenic HTNV in the BSL-3 laboratory. We measured a dose-dependent inhibition of HTNV replication, with no impact on viability under our experimental conditions. Our 
findings indicate that targeting the sodium hydrogen exchanger could be a novel strategy to combat pathogenic HTNV.

In order to identify novel antiviral compounds from natural sources, we screened a phytochemical library. We identified five positive hits from the screen, and conducted further assays to characterize and validate their impact on virus infection. Two natural compounds demonstrated virus-specific activity. Rotenone showed antiviral activity mainly against ANDV-G and LASV-G. It was previously demonstrated to suppress the growth of Newcastle disease and herpes simplex viruses [29], as well as disrupting replication of western equine encephalitis viruses [30]. Nitrarine dihydrochloride, which is prescribed as an antihypertensive, sedative, antispastic and spasmolytic, has not been previously described as an antiviral. However, in our screening, EBOV-G and ANDV-G entry was drastically reduced in the presence of nitrarine dihydrochloride. Upon receptor-mediated endocytosis, EBOV, LASV, HTNV and ANDV are delivered to acidified endosomal compartments, where low $\mathrm{pH}$ is required for membrane fusion [31-34]. In the case of EBOV, LASV and ANDV, the fusion occurs in the late endosomes/lysosomes, while HTNV fuses in the early endosomes [9]. Since nitrarine and rotenone mainly have antiviral activity against EBOV-G, ANDV-G and LASV-G, this suggests that these two compounds are likely to block viruses that fuse in the late endosomal compartment.

Three additional compounds, tetrandrine, monensin sodium salt and emetine dihydrochloride seem to have a broad-spectrum inhibitory activity. Even though hanta-, filo-, and arenaviruses are distantly related, they share common features in their lifecycle, that can be blocked by small molecules [35-37]. Tetrandrine, which is used as an antineoplastic, demonstrated potent antiviral activity against all pseudoviruses tested. Interestingly, tetrandrine was shown to inhibit EBOV infection in human monocyte-derived macrophages and showed therapeutic efficacy in mice [38]. The identification of the antiviral activity of tetrandrine using EBOV pseudoviruses confirmed the robustness of our screening platform. The inhibitory activity affects the endosomal transport of viral particles by specifically blocking L-type calcium channels. Monensin sodium salt, an antibacterial and antimalarial drug, can prevent endocytosis by inhibiting the fusion of Semliki Forest virus [39], as well as the transport of viral glycoproteins to the cell surface [40]. More interestingly, monensin was previously shown to inhibit HTNV replication [41]. Emetine dihydrochloride, an antiamebic, is a well-known inhibitor of cellular protein synthesis [42,43], viral RNA synthesis of SARS-CoV-2, Dengue, Zika and Ebola virus, as well as blocking EBOV entry [43-45]. By investigating entry and post-entry steps of VHFs, we demonstrated that monensin sodium salt can block entry, most likely by inhibiting exit of endosomal compartment, whereas emetine dihydrochloride probably inhibits viral replication.

By validating EIPA, emetine dihydrochloride and tetrandrine with authentic pathogenic HTNV, we observed a drastic reduction in infection, confirming again the robustness of our assay. Moreover, the therapeutic index we obtained provides additional evidence that entry inhibitors could be therapeutic strategies to fight hantaviruses infection. Whereas we found a similar impact of EIPA and tetrandrine with the pseudotype virus or the pathogenic HTNV, emetine dihydrochloride was much more potent against the pathogenic HTNV. This increased antiviral effect is likely due to the experimental setting, as the infection was followed during $48 \mathrm{~h}$ in presence of the drugs. During this period, the viruses can replicate and propagate. However, a major limitation in evaluating novel therapeutic strategies against HTNV is the lack of an animal model that exhibits clinical signs of the disease. The exposure of Syrian hamster, ferret, rhesus macaques and common marmoset to HTNV leads to asymptomatic infection [46].

In sum, the screening platform we have developed allows the identification of antiviral compounds against viral hemorrhagic fever viruses. In our study, we have identified several compounds, among them tetrandrine and emetine dihydrochloride, that could be used in novel antiviral strategies against hantaviruses. 
Author Contributions: Conceptualization, J.M., G.T., O.E. and S.R.; methodology, J.M., G.T. and S.R.; software, J.M., O.E.; validation, J.M.; formal analysis, J.M. and S.R.; investigation, J.M. and S.R.; resources, S.R. and O.E.; data curation, J.M. and S.R.; writing-original draft preparation, J.M., G.T. and S.R.; writing-revision, J.M., G.T., O.E., S.R.; supervision, S.R.; project administration, S.R. and O.E.; funding acquisition, S.R. and O.E. All authors have read and agreed to the published version of the manuscript.

Funding: This research was supported by Swiss Federal Office for Civil protection (Vertrag 353008564/ STM, Vertrag 353008560/STM). J.M. was supported by funds from the University of Lausanne to Stefan Kunz.

Institutional Review Board Statement: Not applicable.

Informed Consent Statement: Not applicable.

Data Availability Statement: All data are available under request.

Acknowledgments: We thank the virology team at Spiez Laboratory for helping to establish the Hantaan virus culture and validation experiment. We also thank Gert Zimmer for the gift of the VSV recombinant and Nicole Tischler for the expression plasmid pI18 GPC ANDV. We further thank Connie Schmaljohn for the plasmid pWRG/HTNV-M, and Mark Page for the expression plasmid pCAGGS-GUI14.

Conflicts of Interest: The authors declare no conflict of interest.

\section{References}

1. Vaheri, A.; Henttonen, H.; Voutilainen, L.; Mustonen, J.; Sironen, T.; Vapalahti, O. Hantavirus infections in Europe and their impact on public health. Rev. Med. Virol. 2013, 23, 35-49. [CrossRef]

2. Vaheri, A.; Strandin, T.; Hepojoki, J.; Sironen, T.; Henttonen, H.; Mäkelä, S.; Mustonen, J. Uncovering the mysteries of hantavirus infections. Nat. Rev. Microbiol. 2013, 11, 539-550. [CrossRef] [PubMed]

3. Brocato, R.L.; Hooper, J.W. Progress on the Prevention and Treatment of Hantavirus Disease. Viruses 2019, 11, 610. [CrossRef]

4. Iannetta, M.; Di Caro, A.; Nicastri, E.; Vairo, F.; Masanja, H.; Kobinger, G.; Mirazimi, A.; Ntoumi, F.; Zumla, A.; Ippolito, G. Viral Hemorrhagic Fevers Other than Ebola and Lassa. Infect. Dis. Clin. 2019, 33, 977-1002. [CrossRef] [PubMed]

5. Mayor, J.; Torriani, G.; Rothenberger, S.; Engler, O. T-cell immunoglobulin and mucin (TIM) contributes to the infection of human airway epithelial cells by pseudotype viruses containing Hantaan virus glycoproteins. Virology 2020, 543, 54-62. [CrossRef] [PubMed]

6. Fedeli, C.; Torriani, G.; Galan-Navarro, C.; Moraz, M.L.; Moreno, H.; Gerold, G.; Kunz, S. Axl Can Serve as Entry Factor for Lassa Virus Depending on the Functional Glycosylation of Dystroglycan. J. Virol. 2018, 92. [CrossRef]

7. Jemielity, S.; Wang, J.J.; Chan, Y.K.; Ahmed, A.A.; Li, W.; Monahan, S.; Bu, X.; Farzan, M.; Freeman, G.J.; Umetsu, D.T.; et al. TIM-family proteins promote infection of multiple enveloped viruses through virion-associated phosphatidylserine. PLoS Pathog. 2013, 9, e1003232. [CrossRef]

8. Torriani, G.; Trofimenko, E.; Mayor, J.; Fedeli, C.; Moreno, H.; Michel, S.; Heulot, M.; Chevalier, N.; Zimmer, G.; Shrestha, N.; et al. Identification of clotrimazole-derivatives as specific inhibitors of Arenavirus fusion. J. Virol. 2019, 93. [CrossRef]

9. Torriani, G.; Mayor, J.; Zimmer, G.; Kunz, S.; Rothenberger, S.; Engler, O. Macropinocytosis contributes to hantavirus entry into human airway epithelial cells. Virology 2019, 531, 57-68. [CrossRef]

10. Zimmer, G.; Locher, S.; Berger Rentsch, M.; Halbherr, S.J. Pseudotyping of vesicular stomatitis virus with the envelope glycoproteins of highly pathogenic avian influenza viruses. J. Gen. Virol. 2014, 95, 1634-1639. [CrossRef]

11. Karunamoorthi, K.; Jegajeevanram, K.; Vijayalakshmi, J.; Mengistie, E. Traditional Medicinal Plants. J. Evid. Based Complement. Altern. Med. 2012, 18, 67-74. [CrossRef]

12. Hooper, J.W.; Custer, D.M.; Thompson, E.; Schmaljohn, C.S. DNA Vaccination with the Hantaan Virus M Gene Protects Hamsters against Three of Four HFRS Hantaviruses and Elicits a High-Titer Neutralizing Antibody Response in Rhesus Monkeys. J. Virol. 2001, 75, 8469-8477. [CrossRef] [PubMed]

13. Cifuentes-Munoz, N.; Darlix, J.L.; Tischler, N.D. Development of a lentiviral vector system to study the role of the Andes virus glycoproteins. Virus Res. 2010, 153, 29-35. [CrossRef] [PubMed]

14. Berger Rentsch, M.; Zimmer, G. A vesicular stomatitis virus replicon-based bioassay for the rapid and sensitive determination of multi-species type I interferon. PLoS ONE 2011, 6, e25858. [CrossRef]

15. Oppliger, J.; Torriani, G.; Herrador, A.; Kunz, S. Lassa Virus Cell Entry via Dystroglycan Involves an Unusual Pathway of Macropinocytosis. J. Virol. 2016, 90, 6412-6429. [CrossRef] [PubMed]

16. Lee, H.W.; Lee, P.W.; Johnson, K.M. Isolation of the Etiologic Agent of Korean Hemorrhagic Fever. J. Infect. Dis. 1978, 137, 298-308. [CrossRef] 
17. Cai, Y.; Iwasaki, M.; Beitzel, B.F.; Yu, S.; Postnikova, E.N.; Cubitt, B.; De Wald, L.E.; Radoshitzky, S.R.; Bollinger, L.; Jahrling, P.B.; et al. Recombinant Lassa Virus Expressing Green Fluorescent Protein as a Tool for High-Throughput Drug Screens and Neutralizing Antibody Assays. Viruses 2018, 10, 655. [CrossRef]

18. Saha, B.; Varette, O.; Stanford, W.L.; Diallo, J.S.; Parks, R.J. Development of a novel screening platform for the identification of small molecule inhibitors of human adenovirus. Virology 2019, 538, 24-34. [CrossRef]

19. Borio, L.; Inglesby, T.; Peters, C.J.; Schmaljohn, A.L.; Hughes, J.M.; Jahrling, P.B.; Ksiazek, T.; Johnson, K.M.; Meyerhoff, A.; O'Toole, T.; et al. Hemorrhagic Fever Viruses as Biological Weapons Medical and Public Health Management. JAMA 2002, 287, 405. [CrossRef] [PubMed]

20. Sola-Riera, C.; Gupta, S.; Maleki, K.T.; Gonzalez-Rodriguez, P.; Saidi, D.; Zimmer, C.L.; Vangeti, S.; Rivino, L.; Leo, Y.S.; Lye, D.C.; et al. Hantavirus Inhibits TRAIL-Mediated Killing of Infected Cells by Downregulating Death Receptor 5. Cell Rep. 2019, 28, 2124-2139.e6. [CrossRef]

21. Lalwani, P.; Raftery, M.J.; Kobak, L.; Rang, A.; Giese, T.; Matthaei, M.; van den Elsen, P.J.; Wolff, T.; Kruger, D.H.; Schonrich, G. Hantaviral mechanisms driving HLA class I antigen presentation require both RIG-I and TRIF. Eur. J. Immunol. 2013, 43, 2566-2576. [CrossRef] [PubMed]

22. Jangra, R.K.; Herbert, A.S.; Li, R.; Jae, L.T.; Kleinfelter, L.M.; Slough, M.M.; Barker, S.L.; Guardado-Calvo, P.; Roman-Sosa, G.; Dieterle, M.E.; et al. Protocadherin-1 is essential for cell entry by New World hantaviruses. Nature 2018, 563, 559-563. [CrossRef] [PubMed]

23. Moller-Tank, S.; Maury, W. Phosphatidylserine receptors: Enhancers of enveloped virus entry and infection. Virology 2014, 468-470, 565-580. [CrossRef]

24. Kondratowicz, A.S.; Lennemann, N.J.; Sinn, P.L.; Davey, R.A.; Hunt, C.L.; Moller-Tank, S.; Meyerholz, D.K.; Rennert, P.; Mullins, R.F.; Brindley, M.; et al. T-cell immunoglobulin and mucin domain 1 (TIM-1) is a receptor for Zaire Ebolavirus and Lake Victoria Marburgvirus. Proc. Natl. Acad. Sci. USA 2011, 108, 8426-8431. [CrossRef] [PubMed]

25. Brouillette, R.B.; Phillips, E.K.; Patel, R.; Mahauad-Fernandez, W.; Moller-Tank, S.; Rogers, K.J.; Dillard, J.A.; Cooney, A.L.; Martinez-Sobrido, L.; Okeoma, C.; et al. TIM-1 Mediates Dystroglycan-Independent Entry of Lassa Virus. J. Virol. $2018,92$. [CrossRef]

26. Riblett, A.M.; Blomen, V.A.; Jae, L.T.; Altamura, L.A.; Doms, R.W.; Brummelkamp, T.R.; Wojcechowskyj, J.A. A Haploid Genetic Screen Identifies Heparan Sulfate Proteoglycans Supporting Rift Valley Fever Virus Infection. J. Virol. 2016, 90, 1414-1423. [CrossRef]

27. Kuroda, M.; Fujikura, D.; Nanbo, A.; Marzi, A.; Noyori, O.; Kajihara, M.; Maruyama, J.; Matsuno, K.; Miyamoto, H.; Yoshida, R.; et al. Interaction between TIM-1 and NPC1 Is Important for Cellular Entry of Ebola Virus. J. Virol. 2015, 89, 6481-6493. [CrossRef] [PubMed]

28. Moller-Tank, S.; Kondratowicz, A.S.; Davey, R.A.; Rennert, P.D.; Maury, W. Role of the phosphatidylserine receptor TIM-1 in enveloped-virus entry. J. Virol. 2013, 87, 8327-8341. [CrossRef]

29. Takatsuki, A.; Nakatani, N.; Morimoto, M.; Tamura, G.; Matsui, M.; Arima, K.; Yamaguchi, I.; Misato, T. Antiviral and Antitumor Antibiotics. XX. Effects of Rotenone, Deguelin, and Related Compounds on Animal and Plant Viruses. Appl. Microbiol. 1969, 18, 660-667. [CrossRef] [PubMed]

30. Raveh, A.; Delekta, P.C.; Dobry, C.J.; Peng, W.; Schultz, P.J.; Blakely, P.K.; Tai, A.W.; Matainaho, T.; Irani, D.N.; Sherman, D.H.; et al. Discovery of Potent Broad Spectrum Antivirals Derived from Marine Actinobacteria. PLoS ONE 2013, 8. [CrossRef]

31. Jin, M.; Park, J.; Lee, S.; Park, B.; Shin, J.; Song, K.J.; Ahn, T.I.; Hwang, S.Y.; Ahn, B.Y.; Ahn, K. Hantaan virus enters cells by clathrin-dependent receptor-mediated endocytosis. Virology 2002, 294, 60-69. [CrossRef]

32. Saeed, M.F.; Kolokoltsov, A.A.; Albrecht, T.; Davey, R.A. Cellular entry of ebola virus involves uptake by a macropinocytosis-like mechanism and subsequent trafficking through early and late endosomes. PLoS Pathog 2010, 6, e1001110. [CrossRef] [PubMed]

33. Cifuentes-Munoz, N.; Salazar-Quiroz, N.; Tischler, N.D. Hantavirus Gn and Gc envelope glycoproteins: Key structural units for virus cell entry and virus assembly. Viruses 2014, 6, 1801-1822. [CrossRef]

34. Hulseberg, C.E.; Feneant, L.; Szymanska, K.M.; White, J.M. Lamp1 Increases the Efficiency of Lassa Virus Infection by Promoting Fusion in Less Acidic Endosomal Compartments. MBio 2018, 9. [CrossRef] [PubMed]

35. Hallam, S.J.; Koma, T.; Maruyama, J.; Paessler, S. Review of Mammarenavirus Biology and Replication. Front. Microbiol. 2018, 9 , 1751. [CrossRef]

36. Walter, C.T.; Barr, J.N. Recent advances in the molecular and cellular biology of bunyaviruses. J. Gen. Virol. 2011, 92, 2467-2484 [CrossRef] [PubMed]

37. Salata, C.; Calistri, A.; Alvisi, G.; Celestino, M.; Parolin, C.; Palu, G. Ebola Virus Entry: From Molecular Characterization to Drug Discovery. Viruses 2019, 11, 274. [CrossRef]

38. Sakurai, Y.; Kolokoltsov, A.A.; Chen, C.C.; Tidwell, M.W.; Bauta, W.E.; Klugbauer, N.; Grimm, C.; Wahl-Schott, C.; Biel, M.; Davey, R.A. Two-pore channels control Ebola virus host cell entry and are drug targets for disease treatment. Science 2015, 347, 995-998. [CrossRef] [PubMed]

39. Marsh, M.; Wellsteed, J.; Kern, H.; Harms, E.; Helenius, A. Monensin inhibits Semliki Forest virus penetration into culture cells. Proc. Nati. Acad. Sci. USA 1982, 79, 5297-5301. [CrossRef] [PubMed]

40. Johnson, D.C.; Spear, P.G. Monensin Inhibits the Processing of Herpes Simplex Virus Glycoproteins, Their Transport to the Cell Surface, and the Egress of Virions from Infected Cells. J. Virol. 1982, 43, 1102-1112. [CrossRef] 
41. Schmaljohn, C.S.; Hasty, S.E.; Rasmussen, L.; Dalrymple, J.M. Dalrymple Hantaan Virus Replication: Effects of Monensin, Tunicamycin and Endoglycosidases on the Structural Glyocproteins. J. Gen. Virol. 1986, 67, 707-717. [CrossRef] [PubMed]

42. Grollman, P. Inhibitors of protein biosynthesis, effects of emetine on protein and nucleic acid biosynthesis in HeLa cells. J. Biol. Chem. 1968, 243, 4089-4094. [CrossRef]

43. Yin Low, J.S.; Chen, K.C.; Wu, K.X.; Mah-LeeNm, H.C.J.J. Antiviral Activity of Emetine Dihydrochloride Against Dengue Virus Infection. J. Antivir. Antiretrovir. 2009, 1, 62-71. [CrossRef]

44. Yang, S.; Xu, M.; Lee, E.M.; Gorshkov, K.; Shiryaev, S.A.; He, S.; Sun, W.; Cheng, Y.S.; Hu, X.; Tharappel, A.M.; et al. Emetine inhibits Zika and Ebola virus infections through two molecular mechanisms: Inhibiting viral replication and decreasing viral entry. Cell Discov. 2018, 4, 31. [CrossRef] [PubMed]

45. Ianevski, A.; Yao, R.; Fenstad, M.H.; Biza, S.; Zusinaite, E.; Reisberg, T.; Lysvand, H.; Løseth, K.; Landsem, V.M.; Malmring, J.F.; et al. Potential antiviral options against SARS-CoV-2 infection. Viruses 2020, 12, 642. [CrossRef] [PubMed]

46. Perley, C.C.; Brocato, R.L.; Kwilas, S.A.; Daye, S.; Moreau, A.; Nichols, D.K.; Wetzel, K.S.; Shamblin, J.; Hooper, J.W. Three asymptomatic animal infection models of hemorrhagic fever with renal syndrome caused by hantaviruses. PLoS ONE 2019, 14, e0216700. [CrossRef] 